\title{
Development of Historical Learning Evaluation Instruments Based on High Order Thinking Skills for Riau History course at Departement of History Education in Riau University
}

\author{
$1^{\text {st }}$ Bunari $^{*}$ \\ Lecture in the Department of History \\ Education, Riau University,Pekanbaru, \\ Indonesia \\ Bunari1975@gmail.com \\ $2^{\text {nd }}$ Yuliantoro \\ Lecture in the Department of History \\ Education, Riau University,Pekanbaru, \\ Indonesia \\ toroyuliantoro@yahoo.co.id
}

\author{
$3^{\text {rd }}$ Yanuar Al Fiqri \\ Lecture in the Department of History \\ Education, Riau University,Pekanbaru, \\ Indonesia \\ yanuar.al@lecturer.unri.ac.id
}

Abstract-This research is motivated by the lack of application of the form of HOTS (High Order Thinking Skill) based assessment instruments in the History education study program (FKIP) Riau University. The purpose of this research is to make HOTS-based assessment instruments for Riau History courses, which can later be used to measure and assess the results of student lectures. This research is in the form of research and development ( $R \& D$ ) with a population that is a student of the History education study program (FKIP) Riau University which is used in the process of testing the Learning Evaluation instrument. The research data was obtained in two ways, namely, interviews and literature. After the data is obtained, it is continued with the preparation of HOTS-based learning evaluation instruments. To obtain

\section{INTRODUCTION}

The assessment and evaluation process is one important component in the learning process. This activity is an obligation to be carried out by all educators, both in the elementary, secondary and higher education environments. Because of the results of the evaluation we are able to see the level of success of the learning process that has been applied by the educator. Not only the success of the learning process, evaluation also accurate data, the test instruments used in this study must meet the criteria. The type of instrument used is a HOTS-based learning outcome test. The stages of instrument development began from the preparation of the test items to the examination of items by material experts to measure cognitive aspects of the learning outcomes variable. Test the validity of this study using the point biserial correlation formula. Items that are declared valid will be retained and invalid items will be revised/discarded. The next step is to test the reliability of the items. Instruments are declared feasible to use if they have successfully fulfilled the requirements for validity, reliability and passed trials in small groups and large groups.

Keywords-Test Instrument, High Order Thinking Skill, Riau History, Learning Outcome

has the benefit of identifying various things in the field of education, ranging from trying to diagnose learners 'learning difficulties, as feedback for improving the learning process, ascertaining students' graduation and assessing the effectiveness of the curriculum and educational policies applied in educational institutions, both school and university level.

In the process of evaluating learning outcomes, there are three aspects of learning 
outcomes that must be assessed, namely aspects of cognitive or knowledge, affective or attitude, and psychomotor or physical skills. For cognitive learning outcomes, Anderson divides it into six taxonomic levels consisting of Remembering (C1), Understanding (C2), Applying (C3), Analyzing (C4), Evaluating (C5) and finally creating (C6). These six cognitive levels do not stand alone but are mutually sustainable with each other. Students will be able to master higher cognitive levels if he has succeeded in mastering the cognitive levels below. For example, students will not be able to understand $(\mathrm{C} 2)$ a teaching material if they have not been able to remember (C1) teaching material that they have learned, and so on. The six cognitive levels are further divided into two, namely the low-level thinking domain $(\mathrm{C} 1, \mathrm{C} 2$, and C3) and the high-level thinking domain or HOTS consisting of (C4, C5, and C6) [1].

To assess the six levels of cognitive learning outcomes, the assessment instruments used must be designed so that the questions tested must be able to measure the six cognitive aspects. The ability of lecturers to develop qualified assessment instruments in their lectures is one of the requirements as a true and professional lecturer. Lecturers who teach in tertiary institutions and teach students must be instilled in an understanding that students are different from high school students. Students must have the ability to think highly and have the ability to absorb teaching material better than high school students. The difference between high school students and college students certainly requires different treatment assessment and evaluation of learning outcomes. Learning assessment for students must be dominated by test questions designed to measure their high level of thinking, which means that in evaluating student learning outcomes the questions being tested are no longer dominated by $\mathrm{C} 1, \mathrm{C} 2$, and $\mathrm{C} 3$ which are categorized into the lower realm of thinking, but dominated by $\mathrm{C} 4, \mathrm{C} 5$, and $\mathrm{C} 5$ which belong to the category of high-level thinking/cognitive domain.

From the experience of the lecture process at the Departement of Historical Education, Riau University it can be seen that the lecturers have not yet implemented the process of evaluating student learning outcomes based on High order thinking skills (HOTS). This can be seen from the process of compiling evaluation instruments that are still dominated by $\mathrm{C} 1, \mathrm{C} 2$, and $\mathrm{C} 3$ questions, which means that the items are more structured to measure students' thinking abilities at a low level. The dominance of C4, C5, and C6 cognitive dimensions are not yet visible, even if there are only a very few and can be said to be unable to measure students' thinking abilities at a high level.

From the various explanations and problems that have been explained above, the researcher is interested in compiling a learning evaluation instrument based on High Order Thinking Skills in lectures in the History of Education Study Program at the University of Riau, especially in the Riau History course that is supported by researchers. The results of this study are expected to be a guide for other history education lecturers in preparing HOTS-based learning evaluation instruments in their respective courses.

According to [2], learning is a change in human disposition or capability that lasts for a long time and is not the result of growth. According to[3],in the perspective of behavioristic psychology, learning is a change in behavior that is relatively permanent as a result of practice and experience, while cognitive flow defines learning as the process by which living things make a change based on experiences interacting with the surrounding environment. Then [4] states learning is about a change: the change brought about by developing a new skill,understanding a scientific law, changing an attitude. The change is not merely incidentalor natural in the way that our appearance changes as we get older. Learning is arelatively permanent change, usually brought about intentionally.Gagne and Briggs in [5] state that learning is a series of events that affect students or learning so that changes in behavior as a result of learning are facilitated. This explanation shows that changes in behavior are the result of a learning or learning process. Departing from this information learning does not only occur in the classroom because to be able to achieve a change in behavior, but learning can also be done anywhere and anytime. This is consistent with what Burton said in [6], that learning is a process of changing behavior in 
individuals due to interactions between individuals and individuals with their environment so that they can interact with their environment. Then [7] asserts that learning is an interaction of three elements, namely, students with educators and learning resources in a learning environment. Learning is an aid given by educators so that the process of acquisition of knowledge, mastery of skills, character, and the formation of attitudes and beliefs in students.And [8] state that there are three important components that define what learning is:

(1) Learning is a process, not a product, (2) Learning involves a change in knowledge, beliefs, behavior, or attitudes, (3) Learning is not something done to students, but rather something students themselves do.

From the statement above, it can be concluded that learning is a process that produces a change, and is not focused only on the knowledge aspect, but also changes in attitudes and abilities. Furthermore, Mayer in [9] argues that learning develops in three views, namely: (1) learning occurs when a person strengthens or weakens the relationship between stimulus and response, (2) learning is the addition of knowledge, because when someone learns he tries to put information into long-term memory, (3) learning is the process of constructing knowledge, because when a person learns he actively constructs knowledge in "working memory" Changes in behavior are also characteristic of learning, which can be seen from the increase in skills possessed. In the form of increasing self-confidence, feel the benefits of learning so that it has skills that can be developed more broadly [10].

Learning outcomes according to[11], can be in the form of attaining changes in behavior that tend to settle from the cognitive, affective, and psychomotor domains of the learning process carried out within a certain time. So that it can be understood that through the process of learning the changes in behavior in question are changes in the three regions or domains. Then[12] state that changes in the cognitive area include several processes or stages, namely remembering, understanding, applying, analyzing, evaluating, and creating.
Evaluation as stated by Tyler in [13],is the process of collecting data to determine the extent, in what terms, and the part where educational goals have been achieved. According to[14], evaluation can be given an understanding as an action or activity carried out with the aim to or a process of determining the value of everything in the world of education. This statement was later strengthened by Ngalimun, who stated that evaluation was the process of gathering sufficient evidence to form the basis for determining whether or not there was a change in students [15]. From the various definitions above, it can be concluded that evaluation in learning is a continuous process carried out to find out changes in students after participating in the learning process. Supardi stated that the object of evaluation in the field of education includes: 1) achievement or learning outcomes, 2) attitudes, 3) behavior, 4) motivation, 5) intelligence, 6) talent, 7) emotional intelligence, 8 ) interests, 9) personality and 10) morals [16].

Arifin in [17] suggested that essentially evaluation is a systematic and ongoing process to determine the quality (value and meaning) of something, based on certain considerations and criteria in order to make a decision. Next, he explained several things about evaluation, that:

1. Evaluation is a process, not an outcome (product). The results obtained from the evaluation activity is a picture of quality rather than something, whether it concerns about value or meaning. While the activity to arrive at giving value and meaning is evaluation. The quality description in question is a logical consequence of the evaluation process carried out. The process is certainly carried out systematically and continuously, in the sense of planning, in accordance with procedures and rules, and continuously.

2. The purpose of the evaluation is to determine the quality of something, especially with regard to values and meanings.

3. In the evaluation process, there must be a consideration (judgment). Giving this consideration is basically a basic concept of evaluation. Through this consideration, the value and meaning (worth and merit) of the 
thing being evaluated is determined. Without giving consideration, an activity is not included in the category of evaluation activities.

In the learning system, evaluation is one of the important components and stages that must be taken by the teacher to determine the effectiveness of learning. The results obtained from the evaluation can be used as feedback for teachers in improving and perfecting programs and learning activities [18].

The purpose of the learning evaluation is to find out the effectiveness and efficiency of the learning system both regarding objectives, materials, methods, media, learning resources, environment and the assessment system itself. The evaluation itself functions as (1) psychologically, students always need to know the extent of the activities that have been carried out in accordance with the objectives to be achieved; (2) sociologically, evaluation functions to know whether students are capable enough to enter the community; (3) didactically-methodical evaluation functions to assist teachers in placing students in certain groups according to their abilities and helps teachers improve their learning process; (4) knowing the position of students in the group whether they are intelligent, moderate or lacking; (5) knowing the level of readiness of students in pursuing their education program; (6) helps teachers provide guidance and selection both in order to determine the type of education, majors or grade promotion; (7) administratively, the evaluation functions to provide reports on student progress to parents, and government officials.

From the various explanations above, it can be concluded that evaluation is a series of processes of data collection and assessment carried out systematically and continuously, the results of which can be used as a reference or guide in making a decision. Many things can be evaluated, ranging from educational policies, curriculum, learning processes, and student learning outcomes. And the evaluation referred to in this research is an evaluation of the learning outcomes of the Riau History course, at the Departement of Historical Education, Riau University.
Higher Order Thinking Skills (HOTS) are thought processes that require students to manipulate existing information and ideas in certain ways that give them new understanding and implications. For example, when students combine facts and ideas in the process of synthesizing, generalizing, explaining, doing hypotheses and analysis, until students come to a conclusion. Meanwhile, according to Brookhart in [19], higher-level thinking skills are categorized into 3 parts, namely: (1) "... define higher-order thinking in terms of transfer", (2) "... define it in terms of critical thinking", and (3) "... define it in terms of problem-solving". In this case, the definition of higher-order thinking skills is categorized into 3 parts, namely (1) as a form of transfer of learning outcomes, (2) as a form of critical thinking, and (3) as a problemsolving process. The main purpose of high order thinking skills is how to improve students' thinking skills at a higher level, especially those relating to the ability to think critically in receiving various types of information, think creatively in solving a problem using the knowledge possessed and make decisions in complex situations [20].

The ability to think at a higher level is one of the important competencies in the modern world, so it must be owned by every student [21] Widodo and Kadarwati in [22] also state that by thinking at a high level, students become independent thinkers, the arguments put forward by students can be indicative of the quality of students' abilities. By applying higherorder thinking as one of the learning approaches, it can produce productive learning activities especially in socio-cognitive interactions, for example in terms of (1) giving and receiving assistance; (2) changing and completing information sources; (3) elaborating and explaining concepts; (4) sharing knowledge with friends; (5) giving and receiving feedback; (6) completing tasks in a collaborative form, and (7) contributing to facing challenges. High order thinking skills (HOTS) are also part of the revised Bloom taxonomy in the form of operational verbs which consist of analyzing (C4), evaluating (C5) and creating (C6), it can be used in making test questions (Test Instrument) to measure learning outcomes [23]. 
According to Wahidmurni in[24], the steps to compile HOTS test instrument are actually the same as the steps in compiling test instrument that is not HOTS, only the emphasis is on contextual stimuli with the expected behavior in HOTS. In non-HOTS, a stimulus is also needed but more test questions are arranged without using stimulus. The steps for preparing the HOTS question are as follows: (1) analyze KD and GPA; (2) arranging the test question grid; (3) determine contextual and attractive stimuli; (4) write test question items according to the test grid; (5) specifying answer keys or scoring guidelines.

\section{METHOD}

This research used to research and development method (R\&D) which adopts a 4-D (Four-D) development model. The design of research to develop teaching materials is conducted by referring to Four-D model development (4D) proposed by Thiagarajan and Semmel[25]. With the stages of research namely, define, design, develop, and disseminate. In this study, the 4-D model was modified so that the research stage was carried out to the developing stage.Broadly speaking, research and development consist of three stages, namely:

1. Define which in this case as a preliminary study or needs analysis includes literature study and field studies.

2. Design, namely conceptual definition, operational definition, instrument lattice, instrument writing, and instrument assembly.

3. Develop includes a limited product trial after the trial then the product is revised, revised the limited product trial (individual test, small group test, and large group test), field trials, and product revisions.

The place of this research is in the Departement of Historical Education, Riau University. This research was conducted from March to August 2019. The collection of data used for the preparation of the test instruments grid about the Evaluation of learning outcome in Riau History course was obtained through two ways namely, interviews and literature study. The interview process will be carried out for lecturers and students who attend the Riau
History lecture, to get an overview of the lecture conditions which include the syllabus and lecture RPS as well as books that are sources of learning at the Riau History course. The literature study is then conducted by analyzing the syllabus and RPS to obtain learning indicators which will later be used as a reference in making HOTS-based assessment instrument grids, and also carrying out a literature study of Riau History textbooks as a basic material in the preparation of test item.

To obtain accurate data, the test instruments used in this study must meet the criteria. The type of instrument used is the HOTS-based multiple-choice test. The stages of instrument development beginning from the preparation of items to the examination of items by material experts to measure the cognitive aspects of the learning outcome variable. The validity of the test instrument using the point biserial correlation formula. Items that are declared valid will be retained and items that are not valid will be revised/discarded. After valid items have been obtained, the next step is to conduct a reliability test on the items.

Reliability shows the stability and consistency of a measurement instrument and can help estimate the goodness of measurement in order to obtain data or accuracy. Broadly speaking there are two types of reliability, namely internal and external reliability. Reliability carried out in this study is internal reliability. The instrument reliability calculation in this study uses KR20, which is a test used to answer true or false (dichotomy) about historical material where the test score is given 1 for correct respondents and a score of 0 for respondents who answered incorrectly. HOTSbased Riau history learning evaluation instrument will be declared suitable for use if it has succeeded in getting the results of the reliability test with the minimum criteria sufficient and the maximum criteria very high.

\section{RESULTS AND DISCUSSION}

In accordance with the research method used to produce valid assessment instrument items, namely 4-D. Then the following steps have been taken. Define, at this stage, a preliminary analysis is carried out to determine the 
description of lecture conditions including the composition of the syllabus and lecture RPS as well as books that are a source of learning Riau History course, this process aims to find out what material is given in the Riau history course and its forms of assessment of the results of lectures that have previously been carried out. In the process of analyzing the syllabus and RPS, it was concluded that this course contained the historical process of Riau starting from the Hindu-Buddhist period to the New Order. This material covers the condition of Riau during the Srivijaya kingdom, the coming of Islam into the Riau region and the development of Islamic empires in Riau, the arrival of western nations to Riau and the political, economic and cultural situation of the people in the Dutch colonial era, Riau during the Japanese occupation and the reaction of the Riau people in welcoming the news of Indonesia's independence, the history of the formation of the Riau Province, and the economic and political conditions of the Riau Province during the Old and New Order.

After the material presented in the Riau history course is known, the next step is Design, which among others consists of the process of compiling an evaluation instrument and writing an instrument. As found in the first stage, the assessment instrument for the history of Riau based on High Order Thinking Skill was compiled as follows.

Tabel 1. HOTS Based Test Blueprint

\begin{tabular}{|c|c|c|c|c|c|}
\hline \multirow{2}{*}{$\begin{array}{c}\text { Lecture } \\
\text { Materials }\end{array}$} & \multirow[t]{2}{*}{ Indicator } & \multicolumn{3}{|c|}{ Cognitive Aspect } & \multirow[t]{2}{*}{ Total } \\
\hline & & $\mathrm{C} 4$ & C5 & C6 & \\
\hline \multirow{3}{*}{$\begin{array}{l}\text { Riau during } \\
\text { Classical Time }\end{array}$} & The establishment of the Srivijaya kingdom & $1,2,3,4$ & & & 4 \\
\hline & $\begin{array}{l}\text { Political, social, religious and cultural life in the } \\
\text { Sriwijaya kingdom }\end{array}$ & & $5,6,7,8$ & & 4 \\
\hline & Srivijaya succes in Maritime and intenational Trade & & & 9,10 & 2 \\
\hline \multirow{3}{*}{$\begin{array}{l}\text { Riau during } \\
\text { Islamic time }\end{array}$} & The arrival of Islam in Riau & $11,12,13$ & & & 3 \\
\hline & $\begin{array}{l}\text { The establishment of Islamic kingdoms in Riau } \\
\text { Region }\end{array}$ & & $\begin{array}{c}14,15,16 \\
, 17\end{array}$ & & 4 \\
\hline & $\begin{array}{l}\text { The development of the Siak Kingdom in the } \\
\text { political, economic and social fields }\end{array}$ & & & $\begin{array}{c}18,19 \\
20\end{array}$ & 3 \\
\hline \multirow{6}{*}{$\begin{array}{l}\text { Riau during } \\
\text { Colonial and } \\
\text { Indonesia } \\
\text { Independence } \\
\text { time }\end{array}$} & The arrival of western nations to Riau & 21,22 & & & 2 \\
\hline & $\begin{array}{l}\text { The political and economic relations of the Siak } \\
\text { kingdom with European colonialism }\end{array}$ & & 23,24 & & 2 \\
\hline & $\begin{array}{l}\text { The social, political and cultural conditions of the } \\
\text { Siak kingdom during the Dutch occupation }\end{array}$ & & & 25,26 & 2 \\
\hline & Japanese arrival to the Riau region & 27,28 & & & 2 \\
\hline & $\begin{array}{l}\text { Changes in political, social and cultural conditions } \\
\text { in the Riau region during the Japanese occupation }\end{array}$ & & 29 & 30 & 2 \\
\hline & $\begin{array}{l}\text { The people of Riau welcome Indonesian } \\
\text { independence }\end{array}$ & & 31 & 32 & 2 \\
\hline \multirow{3}{*}{$\begin{array}{l}\text { Riau during } \\
\text { the reign of } \\
\text { the Old Order } \\
\text { and the New } \\
\text { Order }\end{array}$} & The establishment of Riau Province & & 33,34 & & 2 \\
\hline & $\begin{array}{l}\text { The economy and development of Riau province in } \\
\text { the old and new order }\end{array}$ & 35 & 36,37 & & 3 \\
\hline & $\begin{array}{l}\text { Riau Province in the period before and after the } \\
\text { Reformation }\end{array}$ & & 38,39 & 40 & 3 \\
\hline Total & & 12 & 18 & 10 & 40 \\
\hline
\end{tabular}

The process of compiling the test blueprint produces the following questions: at the analysis thinking level (C4) 12 items are arranged, at the evaluation level (C5) 18 items are arranged and at the creating level (C6) 10 items are arranged. the total number of test question items on the HOTS-based assessment instrument that has been arranged is 40 test questions. 
Developt, After the test blueprint and the distribution of question items, have been made, the next step is the process of making a test question based on the test blueprint that has been made previously. After the test instrument is completed, the next step is the process of validity and reliability of the test instruments that have been made. The first is the validation process carried out by experts, here the selected experts are lecturers who teach in Riau History course and lecturers in the Learning evaluation course. Validation by experts is carried out to see the contents of the initial product. This validation aims to get input, suggestions for improvement, as well as an assessment of the initial product before a limited trial is conducted. The validation activity is carried out by providing an initial product script in the form of a blueprint test and HOTS test questions. In this stage, the following suggestions and input are obtained: Reducing the number of questions on the historical material of Riau in the classical period, which discusses the establishment of the Srivijaya kingdom from four items to three items. Adding items to the discussion of the success of Srivijaya in the maritime and trade fields from two questions to three questions. Writing revision / narration on item number: 20,25, 29, 30 , and 38. After the validation and revision of the instrument in accordance with input from experts, Evaluation Instruments Based on High Order Thinking Skills for Riau History course was declared to be feasible to use.

The next step is the process of testing the test instrument as well as measuring the level of validity of each item statistically. In this case, the instrument testing process is carried out to students of the Departement of Historical education at Riau University who have passed the Riau History course. The item validity process will use the Point biserial Correlation statistical formula with the help of the Microsoft Excel program. The results of item validity can be seen in the following table.

Table 2. Result of Test Instrument Validity

\begin{tabular}{ccccc}
\hline Question Number & rValue & rTable & Criteria & Keputusan \\
\hline 1 & 0,368 & 0,338 & Valid & Used \\
2 & 0,376 & 0,338 & Valid & Used \\
3 & 0,376 & 0,338 & Valid & Used \\
4 & 0,509 & 0,338 & Valid & Used \\
5 & 0,411 & 0,338 & Valid & Used \\
6 & 0,393 & 0,338 & Valid & Used \\
7 & 0,411 & 0,338 & Valid & Used \\
8 & 0,443 & 0,338 & Valid & Used \\
9 & $-0,038$ & 0,338 & Drop & Discarded \\
10 & 0,366 & 0,338 & Valid & Used \\
11 & 0,454 & 0,338 & Valid & Used \\
12 & 0,533 & 0,338 & Valid & Used \\
13 & 0,438 & 0,338 & Valid & Used \\
14 & 0,525 & 0,338 & Valid & Used \\
15 & 0,440 & 0,338 & Valid & Used \\
16 & 0,423 & 0,338 & Valid & Used \\
17 & 0,370 & 0,338 & Valid & Used \\
18 & 0,353 & 0,338 & Valid & Used \\
19 & 0,406 & 0,338 & Valid & Used \\
20 & 0,365 & 0,338 & Valid & Used \\
21 & $-0,139$ & 0,338 & Drop & Discarded \\
22 & 0,428 & 0,338 & Valid & Used \\
23 & 0,407 & 0,338 & Valid & Used \\
24 & 0,508 & 0,338 & Valid & Used \\
\hline
\end{tabular}




\begin{tabular}{ccccc}
\hline 25 & 0,378 & 0,338 & Valid & Used \\
26 & 0,520 & 0,338 & Valid & Used \\
27 & 0,362 & 0,338 & Valid & Used \\
28 & 0,015 & 0,338 & Drop & Discarded \\
29 & 0,340 & 0,338 & Valid & Used \\
30 & 0,352 & 0,338 & Valid & Used \\
31 & 0,401 & 0,338 & Valid & Used \\
32 & 0,415 & 0,338 & Valid & Used \\
33 & 0,490 & 0,338 & Valid & Used \\
34 & 0,436 & 0,338 & Valid & Used \\
35 & 0,033 & 0,338 & Drop & Discarded \\
36 & 0,493 & 0,338 & Valid & Used \\
37 & 0,104 & 0,338 & Drop & Discarded \\
38 & 0,351 & 0,338 & Valid & Used \\
39 & 0,382 & 0,338 & Valid & Used \\
40 & 0,402 & 0,338 & Valid & Used \\
\hline
\end{tabular}

From the results of the validity, there are 35 items that are declared valid and will be used, 5 questions that are not valid will be discarded. The next step is to calculate the reliability of the HOTS-based learning outcomes instrument using the KR20 formula. Here is the KR20 calculation formula:

$$
\begin{gathered}
\mathrm{rii}_{\mathrm{ii}}=\frac{\mathrm{k}}{\mathrm{k}-1}\left[1-\frac{\Sigma \mathrm{pq}}{\sigma_{t}^{2}}\right] \\
\mathrm{rii}_{\mathrm{ii}}=\frac{35}{35-1}\left[1-\frac{8,47}{52,7}\right] \\
=0,863
\end{gathered}
$$

The results of calculating the reliability of the instrument produce a value of 0.863 . This value is then compared to the reliability table to find out the resulting reliability criteria.

Tabel 3. Reliability Interpretation table

\begin{tabular}{cc}
\hline rValue & Interpretation \\
\hline $0,800-1,000$ & Very High \\
\hline $0,600-0,799$ & High \\
\hline $0,400-0,599$ & Sufficient \\
\hline $0,200-0,399$ & Low \\
\hline
\end{tabular}

Based on the interpretation table above, it can be stated that the reliability value of the Evaluation Instruments Based on High Order Thinking Skills for Riau History course has a very high-reliability value.

\section{CONCLUSIONS}

Based on the research result, conclusions can be obtained as follows: (1) the final product in this research is a produces Evaluation Instruments Based on High Order Thinking Skills to measure the learning outcome of Riau History course. It consists of 35 multiple-choice questions. The test question instrument was developed through four steps of development, namely: (a) Define, (b) Design (c) and developt The validity of the instrument was proven by the results of expert evaluations which showed that the instrument was appropriate to be used based on the review of material, construction, and language aspects. Based on a statistical validity trial of 40 questions that have been compiled, it obtained 35 items that were declared valid. And based on the results of the reliability calculation, HOTS-based learning evaluation instruments that have been developed have very highreliability criteria. Based on some of the results above, it can be concluded that the HOTSbased learning evaluation instrument that has been developed has been appropriate to be used to measure student learning outcomes in the Riau History course at Riau University.

\section{ACKNOWLEDGMENTS}

Authors acknowledge to anyone who has helped during the research. 


\section{REFERENCES}

[1] Wahyuni, Yusri dan Fauziah, Higher Order Thinking Skill Instrumen Design of Student-Based on Bloom's Taxonomy. (2018). American Journal of Engineering Research, 7(8).

[2] Gredler, Margaret E. (2011). Learning and Instruction: Teori dan Aplikasi,terjemahan Tri Wibowo. Jakarta: Remaja kencana.

[3] Spencer A. Rathus. (2010). Psychology: Concepts and Connections. Belmont: Wadsworth.

[4] Sequeira, A.H. Introduction to Concepts of Teaching and Learning. (2012). SSRN Electronic Journal.

[5] Suparman, Atwi. (2012). Desain Instruksional Modern,Jakarta: Erlangga. dengan Penerapan HOTS (High Order Thinking Skills). Bandung: SMILE's Publishing.

[6] Siregar, Eveline dan Hartini Nara. (2011). Teori Belajar dan Pembelajaran. Bogor: Ghalia Indonesia.

[7] Suandi, Moh. (2018). Belajar dan Pembelajaran. Yogyakarta:Deeppublisher.

[8] Ambrose, Susan. dkk, (2010). How Learning Work: Seven Research-Based Principles for Smart Teaching, San Francisco: Jossey-Bass.

[9] Gasong, Dina. (2018). Belajar dan Pembelajaran, Yogyakarta: Deeppublisher.

[10] Daryanto, Rahmawati. (2015). Teori Belajar dan Proses Pembelajaran yang Mendidik. Yogyakarta: Gava Media.

[11] Jihad, Asep dan Abdul Haris. (2010). Evaluasi Pembelajaran. Yogyakarta: Multi Presindo.

[12] Anderson, Lorin W. dan David R. Krathwohl. (2015). Kerangka landasan untuk pembelajaran, pengajaran dan asesmen. Jakarta: Pustaka Pelajar.

[13] Arikunto, Suharsimi. (2015). Dasar-dasar Evaluasi Pendidikan. Jakarta: Bumi Aksara.

[14] Sudijono, Anas. (2011). Pengantar Evaluasi Pendidikan. Jakarta: Raja Grafindo Persada.
[15] Ngalimun. (2018). Evaluasi dan penilaian pembelajaran. Yogyakarta:Parama Ilmu.

[16] Supardi. (2016). Penilaian Autentik: Pembelajaran Afektif, Kognitif, dan Psikomotorik. Jakarta: RajaGrafindo Persada

[17] Asrul,dkk. (2014). Evaluasi Pembelajaran. Bandung: Ciptapustaka Media.

[18] Arifin, Zainal. (2015). Evaluasi Pembelajaran Prinsip Teknik Prosedur. Bandung: PT Remaja Rosdakarya.

[19] Hidayati, A. U. (2017). Melatih Keterampilan Berpikir Tingkat Tinggi dalam Pembelajaran Matematika pada Siswa Sekolah Dasar. Jurnal Pendidikan dan Pembelajaran Dasar.

[20] Saputra, Hatta. (2016). Pengembangan Mutu Pendidikan Menuju Era Global: Penguatan Mutu Pembelajaran.

[21] Widana, I. W. (2017). Modul Penyusunan Higher Order Thingking Skill (HOTS). Direktorat Pembinaan Sma Direktorat Jenderal Pendidikan Dasar dan Menengah Departemen Pendidikan dan Kebudayaan 2017.

[22] Dan Sri Kadarwati, T. W. (2013). Higher Order Thinking Berbasis Pemecahan Masalah untuk meningkatkan Hasil Belajar Berorientasi Pembentukan Karakter Siswa. Jurnal Cakrawala Pendidikan,

https://doi.org/10.21831/cp.v5i1.1269

[23] Fanani, M. Z. (2018). Strategi Pengembangan Soal Higher Order Thinking Skill (HOTS) dalam Kurikulum 2013. Edudeena.

[24] Wahidmurni, Pengembangan Penilaian untuk Mengukur Kemampuan Berpikir Tingkat Tinggi (Higer Order Thinking Skills/HOTS). Workshop Pengembangan Penilaian Kurikulum 13 Bagi Guru-guru Madrasah Aliyah Negeri Batu. 13 Juli 2018.

[25] Mappalotteng, Abdul Muis, Et.al, The Development of Programmable logic controller tutorial in the form of industrial-based learning material in vocational high schools. Research Inventy: International Journal of Engineering and Science, 5(5). 